\title{
Influências dos tecidos e das estamparias africanas na identidade $\mathbf{e}$ na cultura afro-brasileiras
}

The legacy of African fabrics and stamping to afro brazilian identity and culture

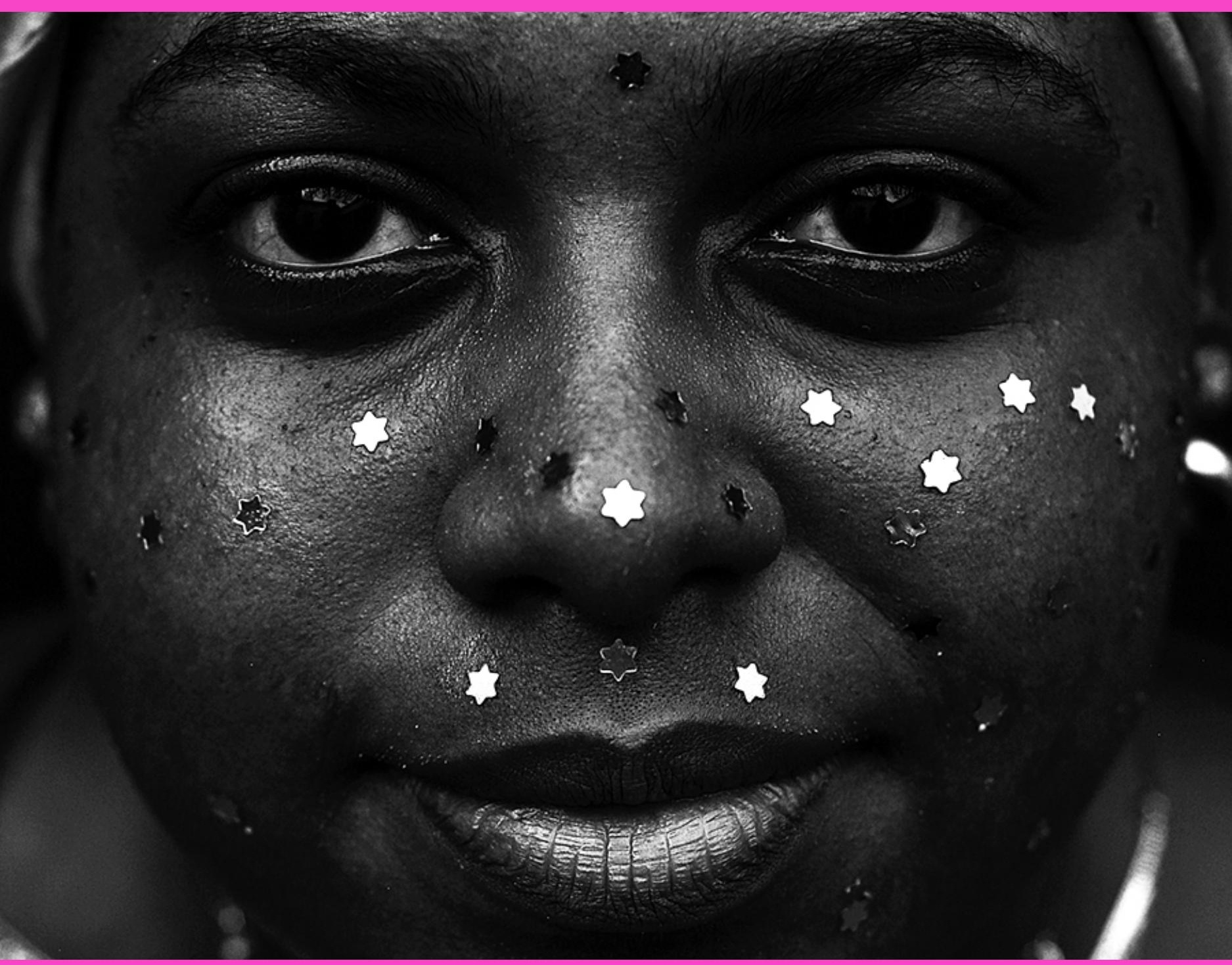




\section{Julia Vidal ${ }^{1}$}

ORCID: https://orcid.org/0000-0003-4083-2699

\section{Dyego de Oliveira Arruda}

ORCID: https://orcid.org/0000-0002-9514-284X

[resumo] Este artigo se propõe a apresentar os tecidos e as estamparias africanas como veículos de identidades híbridas, que constroem uma trama de saberes ao longo de suas articulações econômicas, culturais e sociais. Por meio de pesquisas bibliográficas e entrevistas, pretendemos compreender o papel social dos tecidos Wax, Adinkra e Ofi/Pano da Costa como patrimônios culturais que preservam e transmitem aspectos da história e da filosofia, além de valores e normas socioculturais, dos povos da África. Esses tecidos ganham importância ao se apresentarem como telas de representação do jogo de identidades africanas e renovações identitárias afro-brasileiras. Para o fortalecimento da memória e conscientização das contribuições africanas no Brasil, propomos o estudo dos tecidos africanos, de suas narrativas em estamparias e dos seus usos cotidianos como ferramentas de autoinscrição e de difusão do legado de resistência dos povos africanos em diáspora pelo mundo.

\section{[palavras-chave] Tecidos. Moda. Estamparia. Identidade afro-brasileira. Cultura.}

[abstract] This article aims to present African fabrics and prints as conduit of hybrid identities, which build a web of knowledge along their economic, cultural and social articulations. Through bibliographic research and interviews, we aim to understand the social role of Wax, Adinkra and Ofi/Pano da Costa fabrics as cultural heritages that preserve and conveys aspects of history, philosophy, values and sociocultural norms of the peoples of Africa. These fabrics become increasingly important as they present themselves as a representation screen of African identities and Afro-Brazilian identity renewals. In order to strengthen the national memory and to raise the awareness of African contributions in Brazil, we propose the study of African fabrics, their stamping narratives and their everyday uses as a tool for spreading the legacy of resistance of African peoples in diaspora throughout the world.

[keywords] Fabrics. Fashion. Stamping. Afro-Brazilian identity. Culture.

Recebido em: 30-12-2019

Aprovado em: 17-05-2020

\footnotetext{
${ }^{1}$ Mestre pelo Programa de Pós-Graduação em Relações Étnico-Raciais (PPRER) do Centro Federal de Educação Tecnológica Celso Suckow da Fonseca (CEFET/RJ), Rio de Janeiro, Brasil. É designer de moda e professora do Instituto Europeu de Design (IED), no Rio de Janeiro. E-mail: julia@juliavidal.com. br. Lattes: http://lattes.cnpq.br/5696333406832552.

2 Doutor em Administração de Organizações pela Universidade de São Paulo (USP). Realizou estágio de Pós-Doutorado em Administração na Universidade Federal de Mato Grosso do Sul (UFMS). É professor do Centro Federal de Educação Tecnológica Celso Suckow da Fonseca (CEFET/RJ), no Rio de Janeiro, credenciado no Programa de Pós-Graduação em Relações Étnico-Raciais (PPRER) da instituição. E-mail: dyego.arruda@gmail.com. Lattes: http://lattes.cnpq.br/5222976964204691.
} 


\section{Aspectos introdutórios}

Ao longo dos processos históricos de constituição dos Estados modernos, seja na Ásia, na Europa ou nas Américas, os povos originários da África foram (e ainda são) agentes ativos no desenvolvimento da civilização humana, legando elementos identitários, costumes, ritos, indumentárias e expressões artísticas às sociedades contemporâneas (NASCIMENTO; GÁ, 2009; SILVA, 2018).

Os alimentos, as matérias-primas, as vestimentas e os próprios sujeitos provenientes do continente africano influenciaram hábitos e formas de expressão presentes no cotidiano do brasileiro (FERREIRA, 2019). Nesse ínterim, o consumo corriqueiro de feijoada ou mesmo de acarajé, a presença do samba como gênero musical característico do país, além do tradicional culto a determinados orixás, no âmbito da umbanda ou do candomblé, são alguns poucos exemplos da miríade de múltiplas influências, diretas ou indiretas, dos povos africanos na constituição de uma trama de elementos identitários do povo brasileiro (SANSONE, 2000).

Entre as extensões das diversas culturas do continente africano no Brasil, vale destacar os legados relacionados à produção têxtil, em forma de tecidos estampados e vestimentas tradicionais da indumentária afro-brasileira. Ao perpetuar histórias e costumes, os tecidos e as estamparias alcançaram uma dimensão de patrimônio cultural uma vez que permitiram o exercício de alinhavar identidades culturais por meio de cores, matérias-primas, formas de produção, símbolos e narrativas culturais (CARISE, 1974).

Histórias em formas de símbolos decorativos em tecidos são uma tradição relembrada e revivida de forma ancestral no cotidiano, e vão além das fronteiras dos países de origem, ampliando o senso de comunidade e a identidade africana na diáspora pelo mundo.

Neste artigo, apresentaremos os tecidos e as estamparias Wax ${ }^{3}$, Adinkra e Ofi/Pano da Costa como formas de escrita não tradicional; como um sistema de transmissão de saberes que se liberta da tradição logocêntrica ${ }^{4}$ e nos apresenta maneiras diferenciadas de saberes cognitivos instaurados em uma compreensão semiótica relacionada aos símbolos, às produções, às representações e às tradições culturais africanas vivas pelo globo.

A escolha desses tecidos se deu em função de eles terem se difundido, na diáspora, como patrimônio simbólico e identitário das múltiplas "Áfricas", sobretudo a nigeriana e a ganesa, no Brasil. Suas estamparias e tramas veiculam filosofias ancestrais milenares, narrativas e tradições de produção têxtil, ao passo que suas origens e suas ressignificações são valiosas para que possamos compreender a complexidade de identidades híbridas constantemente (re)valorizadas ao longo dos inúmeros trânsitos territoriais e rotas comerciais.

\footnotetext{
${ }^{3}$ Vale salientar que o tecido Wax, muito embora seja fisicamente fabricado na Holanda, é compreendido, no âmbito deste estudo, como um tecido africano, uma vez que a "produção" dos seus significados e usos mais correntes estão fortemente relacionados à história e à cultura dos povos africanos. Mais adiante retomaremos esses aspectos, com base nas entrevistas realizadas para a construção deste artigo.

${ }^{4} \mathrm{~A}$ tradição logocêntrica refere-se à dimensão epistemológica que coloca a palavra como o centro do conhecimento. Dessa maneira, toda forma de transmissão de conhecimentos e saberes estaria centrado na comunicação pela palavra.
} 
Sendo assim, vale dizer que os tecidos assumem grande importância à medida que se mostram como tela de representação para o melhor entendimento do processo de construção da identidade afro-brasileira. Nas palavras de Hall, “as identidades nacionais não são coisas com as quais nós nascemos, mas são formadas e transformadas no interior da representação" (HALL, 2006, p. 48).

A partir dos fios, das tramas, das estamparias, dos trânsitos comerciais e dos usos dos tecidos, podemos compreender a complexidade, a diversidade e a hibridez provenientes do continente africano, além das novas identidades assumidas, potencializadas e (re)valorizadas no território brasileiro (GILROY, 1993).

De todo modo, ante à contextualização acima apresentada, uma questão de pesquisa que por ora surge é a seguinte: de que modo tecidos e estamparias de origem africana contribuíram para a constituição da identidade e da cultura afro-brasileiras?

Portanto, com base na supracitada problemática de pesquisa, o presente artigo tem como objetivo compreender as potenciais influências dos tecidos e das estamparias Wax, Adinkra e Ofi/Pano da Costa na composição de elementos identitários e culturais no Brasil.

Julgamos que um processo de reflexão em torno da problemática e do objetivo deste artigo representa um esforço relevante, principalmente para que se possa valorizar e catalisar a potência da cultura africana em diáspora pelo mundo, sobretudo no que tange às contribuições da África para a constituição da identidade e da cultura do povo brasileiro.

\section{Identidade e cultura afro-brasileira: apontamentos preliminares}

Ao longo da história, o conceito de identidade passou, constantemente, por reformulações e reinterpretações. Stuart Hall (2006) relaciona o processo de construção de tal construto teórico com períodos históricos, sinalizando que no Iluminismo, a identidade do sujeito possuía um caráter fixo, individualista e calcado na razão. Segundo o mesmo autor, com a maior complexidade inerente à vida nas sociedades ditas "modernas", a identidade passa a ser estabelecida de forma relacional, ou seja, a partir das inter-relações com os demais membros da comunidade. Por fim, com o advento da pós-modernidade e da sociedade em rede, a identidade passa a ser mais fragmentada e difusa, implicada em uma verdadeira troca de hábitos, comportamentos, costumes e ritos que notadamente fizeram com que as pessoas manifestassem performances cada vez mais variadas, transformadas e, portanto, fluidas (HALL, 2006). Nesse cenário, as tensões entre as identidades são deflagradas pelas novas articulações em decorrência dos contatos contínuos com o "outro", representado nas diferenças, em choque ao longo dos processos de interação social.

Paul Gilroy (1993), ao analisar a perspectiva identitária das pessoas negras em diáspora pelo mundo, apresenta o conceito de dupla consciência, no qual os sujeitos são e não são negros, são e não são europeus, são e não são modernos, assumindo uma duplicidade anunciada anteriormente por Du Bois (1994), que ressaltava a dualidade da perspectiva colonial vivida na modernidade como "[...] dois ideais em guerra em um só corpo escuro, cuja força tenaz é apenas o que o impede de se dilacerar" (DU BOIS, 1994, p. 2) 5 .

\footnotetext{
${ }^{5}$ Tradução nossa para: "[...] two warring ideals in one dark body, whose dogged strength alone keeps it from being torn asunder".
} 
Nesse ínterim, pode-se perceber a perspectiva da identidade como uma dualidade, ou seja, um determinado corpo, ao manifestar-se, seria a morada de duas almas, duas formas de pensamento, muitas vezes antagônicas, não raro, imbricadas e coerentes com determinados papéis que se quer assumir ao longo das interações sociais (GOFFMAN, 2014). Nesta pesquisa foi possível perceber - conforme descreveremos mais adiante - que os tecidos assumem, em muitas circunstâncias, identidades duplicadas, em um verdadeiro jogo de disputas de significados.

Vale dizer que a era pós-moderna caracterizou-se por um processo contínuo de renovações, por uma dinâmica em que as identidades, em constante articulação, irão revelar-se fragmentadas e fraturadas e, em seus trânsitos, serão (re)construídas por meio de tramas que compõem discursos, práticas e expressões artísticas. 0 processo de identificação será constantemente ressignificado pelo sujeito durante a experiência da modernidade, transformando-se continuamente dentro dos sistemas culturais que o rodeiam, inaugurando as identidades complexas, contraditórias, deslocadas e híbridas.

As identidades híbridas irão se configurar por meio de enlaces dos trânsitos continentais, migrações nacionais e regionais, nos meios de urbanização e de globalização, tornando-se tramas de negociações de identidades deslocadas, em constantes (re)apropriações. No transcurso da globalização, instaura-se um sistema de circularidade de ideias e culturas, além da ampliação de universos simbólicos, que se torna um marco de referência para a criação de identidades e de estratégias de sobrevivência tanto das camadas populares quanto das elites.

Como bens culturais, os tecidos e as estamparias étnicas serão comercializados e apresentados para novos mercados consumidores. Para se fazerem presentes em territórios e no cotidiano de outras culturas, irão incorporar símbolos, articular tradições e tecnologias, além de participar de novas formas de representação. Suas identidades irão assumir cotidianamente uma assimilação do particular (ou local) ao universal, somada a uma (re)invenção das tradições, mútua e continuamente.

Nesse ambiente em que se configuram as culturas híbridas, faz-se o jogo de (re)configurações culturais, no qual poderemos perceber disputas de narrativas identitárias que evidenciaram a dupla consciência, anteriormente associada aos interesses do capital, próprios das indústrias que buscam extrapolar fronteiras e ganhar maiores parcelas do mercado consumidor.

As apropriações culturais acontecerão nesse contexto e estarão em disputa, podendo haver o apagamento de um discurso ou de uma cultura pelo outro. 0 problema das apropriações culturais dá-se quando, na disputa por uma ampliação de mercado, uma cultura hegemônica reforça sua preponderância, afirmando-se a partir do apagamento da autoria e da origem de símbolos e tradições de uma cultura pela outra (WILLIAM, 2019).

A característica fundamental desses processos é não se tratar mais de identidades nacionais que, descoladas, se mantém em novos territórios. Aqui abordamos identidades que, ao longo de suas viagens, tornam-se abertas, incorporam outras identidades, ampliam-se, assimilam e/ou apagam etnicidades e símbolos, configurando novas formas de existências após seus trânsitos.

Dessa forma, chamamos a atenção para o corpo como "espaço" que irá (re)territorializar, incorporar e apresentar as negociações identitárias resultantes dessa trama, que não 
se constitui de retalhos costurados entre si, mas se apresenta como um novo tecido, no qual cada fio confere a diversidade e os entrelaçamentos que darão origem a uma estética. Rodrigues Jr. (2018) vai discutir o corpo como espaço quando apresenta o conceito de "corpo terreiro" (RODRIGUES JR, 2018, p. 84), evocando o termo "terreiro" como local que materializará memórias e tradições africanas, para uma vivência dessas experiências diaspóricas no corpo afro-brasileiro.

Os corpos das diversas "Áfricas" chegam ao Brasil com suas marcas, seus cortes, seus penteados de cabelo e suas amarrações em tecidos, em uma dinâmica na qual essas expressões estéticas se apresentam como elementos identitários de diferentes origens étnicas africanas. Ao longo das lutas por direitos civis e pela valorização da cultura afro-brasileira, esse corpo será o espaço que vai apresentar os "saberes estético corpóreos", como ressalta Gomes (2017, p. 76), que também descreverá esse evento como "movimento negro educador" (GOMES, 2017, p. 75).

Dessa forma, podemos apontar como saberes estéticos as estampas africanas que pousam sobre esse corpo, agora brasileiro, veiculando símbolos de diversas identidades culturais e atribuindo vida a uma moda política e afro-brasileira em novo território.

\section{Delineamentos metodológicos da pesquisa}

Para seguirmos refletindo sobre os tecidos africanos como patrimônios que perpetuam símbolos, tradições, saberes e identidades, empreendemos uma pesquisa empírica, em que foram utilizados como critério de seleção, para fins de análise, os tecidos de maior representação comercial, produção e uso por afrodescendentes brasileiros no século XXI.

Sendo assim, este estudo se debruçou em três tecidos africanos de grande difusão no Brasil, o Ofi/Pano da Costa, o Adinkra e o Wax. Tais tecidos foram escolhidos - conforme já se fez menção na introdução deste trabalho - por serem usados cotidianamente, em territórios africanos e no Brasil, como símbolos de identidade afro-brasileira na atualidade. Sua origem e suas ressignificações foram valiosas para que pudéssemos compreender a complexidade de identidades híbridas constantemente (re)valorizadas ao longo dos seus inúmeros trânsitos territoriais e rotas comerciais.

Para a obtenção dos dados necessários para a pesquisa, conduzimos uma análise qualitativa e interpretativa de documentos bibliográficos que concentram informações alusivas ao comércio de tecidos africanos e afro-brasileiros, imagens do seu uso no cotidiano, além dos registros fotográficos do acervo dos autores e de comerciantes de tecidos africanos no Rio de Janeiro, São Paulo e Salvador (os principais centros de difusão e de comercialização dos itens sob análise neste estudo).

Ademais, foram realizadas três entrevistas com pessoas, atualmente residentes no Brasil, que desempenham atividades relativas ao comércio de vestimentas ou de tecidos africanos e que conhecem profundamente os detalhes dos significados e usos inerentes aos panos.

Em conformidade com os princípios que regem a ética na pesquisa, vale frisar que as três pessoas entrevistadas receberam um Termo de Consentimento Livre e Esclarecido 
(TCLE) em que foram especificados os detalhes do estudo e o compromisso dos investigadores em usarem os dados para fins estritamente acadêmicos. As três pessoas que efetivamente concederam a entrevista assinaram o TCLE - atualmente, arquivado com a equipe que coordenou a pesquisa.

Com o propósito de manter sob sigilo a identidade dos depoentes, adotaremos o expediente de identificá-los por intermédio de categorias institucionais, relacionadas ao desempenho profissional das pessoas. Portanto, os entrevistados serão designados, ao longo da análise e da discussão dos resultados deste estudo, como comerciante (entrevistado C), administrador (entrevistado A) e estilista (entrevistado E).

A escolha dos sujeitos de pesquisa se deu pelo critério de buscar pessoas naturais do continente africano e que, atualmente, possuem protagonismo nos esforços de difusão dos tecidos africanos no Brasil. Sendo assim, os entrevistados perfazem atores que compreendem as culturas africana e brasileira, e estão aptos para o fornecimento de informações que nos propiciem estabelecer paralelos e articulações identitárias e suas formas de representação.

Em resumo, o "comerciante" é nigeriano e vive entre suas casas na Nigéria e no Rio de Janeiro, comercializando tecidos e roupas para lojistas. 0 "administrador" é da Costa do Marfim e vive em São Paulo; é professor e administrador de uma loja que vende tecidos africanos para estilistas e consumidores finais. A “estilista” é angolana e vive no Rio de Janeiro, tem sua própria marca de moda, cria coleções reproduzindo estamparias tradicionais africanas e vende tais produtos para consumidores finais.

Vale dizer, por fim, que as três entrevistas foram gravadas com o consentimento pleno dos participantes para posterior transcrição. Usamos, como subterfúgio para a discussão dos dados, a análise de conteúdo, que representa uma técnica que tem como escopo, a partir de um viés crítico e interpretativo, sistematizar os dados da pesquisa com o propósito de identificar categorias e/ou fragmentos de textos que elucidem, de alguma forma, as problemáticas de pesquisa que norteiam a investigação (BARDIN, 2011).

\section{Tecidos que contam histórias}

Existem "muitas Áfricas" na África. Esse continente africano é diverso em suas culturas, climas, idiomas e expressões artísticas. Lopes e Falcón (2010) ressaltam a diversidade étnica nas produções artísticas africanas e a tecelagem tradicional como integrante de "um vasto acervo de manifestações culturais ou artísticas que caracterizam o mundo africano" (LOPES; FALCÓN, 2010, p. 16). Os autores destacam ainda a estamparia em tecido como um "alfabeto visual" (LOPES; FALCÓN, 2010, p. 18) formado por um arranjo de signos que propiciam uma leitura plástica e apresentam os simbolismos africanos e seus mundos imateriais.

No âmbito da produção têxtil africana, cada região apresenta uma variedade de panos, dos quais se destacam o Kente e o Adinkra, de Gana; o Adire e o Ofi/Pano da Costa, da Nigéria; o Bogolan, do Mali; o Velours du Kasaï, da República Democrática do Congo; 
além do Arkilla, da Costa do Marfim. Cada um desses tecidos expressa cultura e saberes locais que, de forma dinâmica, viajam e são absorvidos em novos territórios e culturas, podendo ganhar revalorizações estéticas e identitárias a partir da experiência de seus trânsitos (VIDAL, 2014).

O tecido Ofi/Pano da Costa, conforme apontou a nossa pesquisa, é alusivo ao povo nigeriano, correspondente ao grupo étnico Yorùbá, embora seu uso também possa ser encontrado entre povos da Costa do Marfim, Gana, Congo, Benin e Senegal como parte do seu vestuário. Ao chegar no Brasil, foi o primeiro tecido a cobrir os corpos africanos, conforme apontam os registros de Jean-Baptiste Debret e Johann Moritz Rugendas (BANDEIRA; LAGO, 2013; RUGENDAS, 1998).

No Brasil, segundo Torres (1950), o Ofi/Pano da Costa ficou também conhecido como pano de cuia graças à acomodação das bandas do tecido enroladas em cuias redondas e chatas no ato de sua comercialização, mas foi como Pano da Costa que ganhou mais repercussão. 0 termo apresenta o local de origem implícito, assim como a palha da costa, o búzio da costa, a pimenta da costa, entre outras mercadorias que, segundo Lody (2015), tiveram seu comércio intensificado "da costa" africana para o Brasil a partir do século XVI. O sufixo "da costa" era dado aos produtos de maior representatividade comercial, provenientes da costa ocidental africana. Tal tecido estará presente nas indumentárias crioulas e acompanhará a vestimenta de sair, sendo usado como xale e/ou repousado no ombro, em situações sociais. Nas ocasiões de trabalho, dará maior apoio ao movimento do corpo, reforçando atividades braçais, como as das vendedeiras e lavadeiras, sendo usado amarrado à cintura e chamado de rojão. Em cerimônias religiosas, terá função sagrada, indicando os orixás cultuados no Brasil por meio das cores e formas de amarração do tecido ao corpo, insígnias de cada uma das divindades. As estampas, as cores, a matéria-prima que perfaz o tecido e sua colocação indicam ainda as posições hierárquicas no contexto religioso.

Lody (2015) evidencia a chegada do Pano da Costa como uma peça de simbolismo cultural, histórico, social e religioso no Brasil contemporâneo. Seu nome não é reconhecido na África e, a partir das entrevistas com os atores envolvidos na comercialização de panos africanos no Brasil, foi possível saber que o nome comumente utilizado na África é Ofi, de origem Yorùbá, da Nigéria.

Vale dizer que o Ofi, na África, também pode ser designado pelo termo Aso Òkè, que significa pano ou roupa de alto status. Vestido em grandes ocasiões, como casamentos, batizados, cerimônias políticas, religiosas ou em funerais, o Aso Òkè perfaz um traje tradicional completo feito com o Ofi. Quando veste o homem, esse traje é composto por camisola (agba$d a$ ) e chapéu (fila); ao vestir a mulher, é composto por blusa ( $b u b a)$, saia (iro), xale ou faixa sobre o ombro (ipele) e turbante $(\text { gele })^{6}$.

\footnotetext{
${ }^{6}$ Neste artigo, não nos dedicaremos à análise do traje completo Aso Òkè, por isso optamos por nos referenciarmos apenas ao tecido por meio do nome Ofi.
} 
FIGURAS 1 E 2 - TECIDO OFI, FEIRA DE SÃO JOAQUIM, EM SALVADOR (BA) (À ESQUERDA), E PANOS DA COSTA PRODUZIDOS NO BRASIL (À DIREITA)
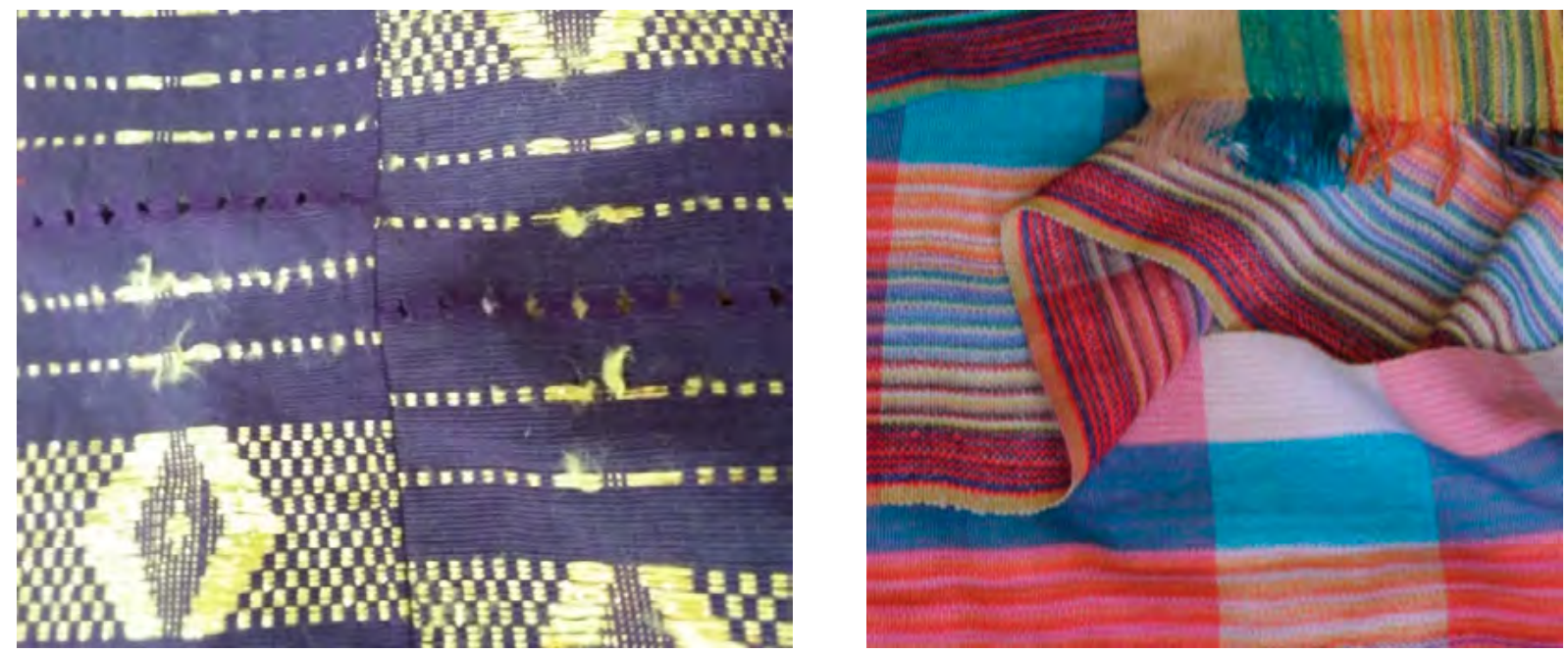

FONTE: Acervo pessoal dos pesquisadores (figura 1); MAURÍCIO, Jorge da Silva. O Pano da Costa. In: BAHIA - Governo do Estado (org.). Pano da Costa: Cadernos do IPAC, 1. Salvador: Ipac, 2009, p. 12-16 (figura 2).

Ressalte-se que o Ofi/Pano da Costa, no Brasil, irá compor o turbante e o xale ou pano de ombro, tradicionais da vestimenta étnico-social afrodescendente. Essa indumentária vestiu as negras de ganho - mulheres comerciantes no século XIX - e hoje se mantém vivo nos trajes tradicionais das baianas e nas indumentárias religiosas de filhos de santo e das Yalorixás (mães de santo), responsáveis pela manutenção de saberes religiosos e culturais das matrizes africanas no Brasil.
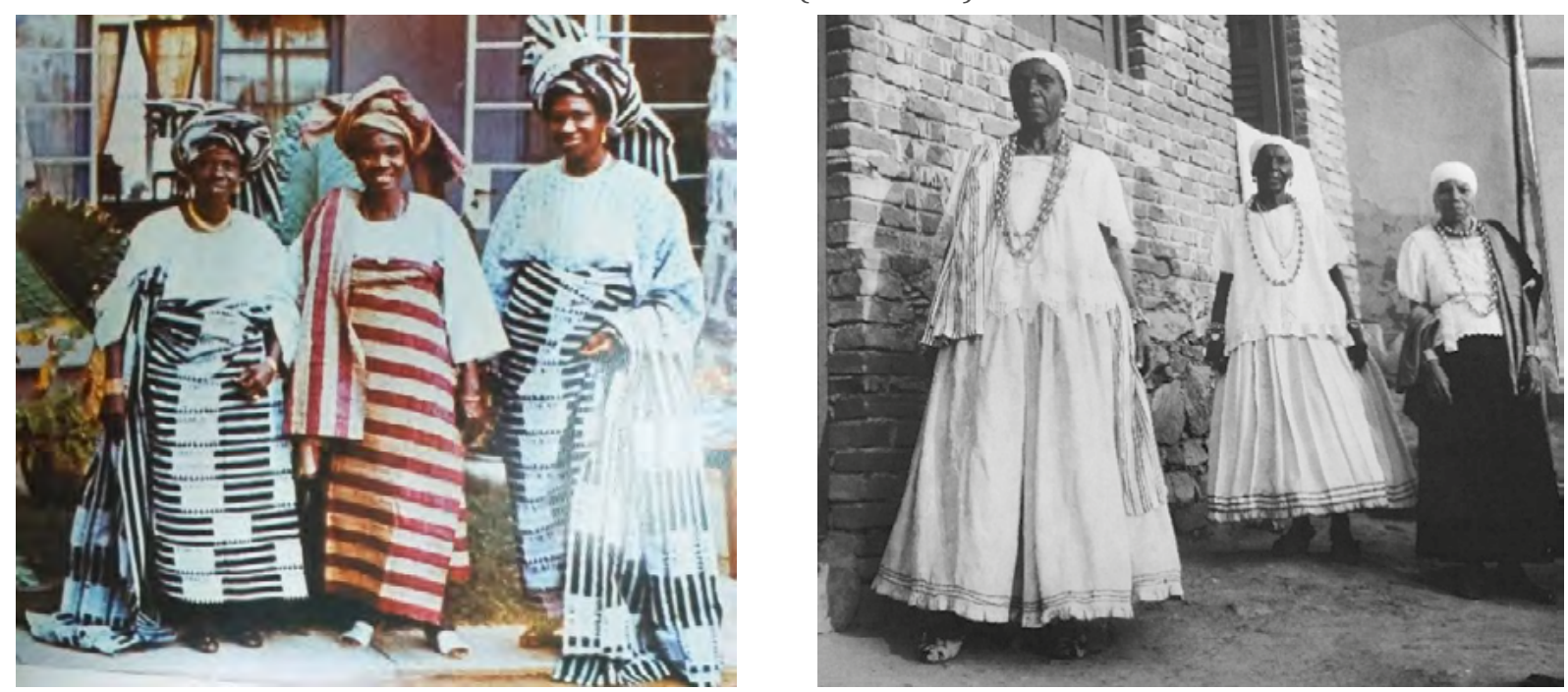

FONTE: EICHER, Joanne Bubolz. Nigerian handcrafts textile. Ilê-Ifé: University of Ifé Press, 1976 (figura 3); LODY, Raul. Moda e história: as indumentárias das mulheres de fé. São Paulo: Editora Senac, 2015 (figura 4). 
Entre as produções têxteis africanas também encontramos, segundo Nascimento e Gá (2009), as padronagens que apresentam imagens humanas ou de animais, relacionadas às filosofias ancestrais fundadoras da cultura dos povos Acã, do grupo étnico Ashanti de Gana, presentes nos tecidos Adinkra, que vestiam os reis Ashanti e hoje são amplamente difundidos e vestidos no cotidiano do cidadão de Gana e do africano em diáspora. A estamparia Adrinkra se propagou como símbolo de poder e identidade étnica de Gana ao redor do planeta. Para nós, além da identidade veiculada, também adquire grande importância como forma de escrita.

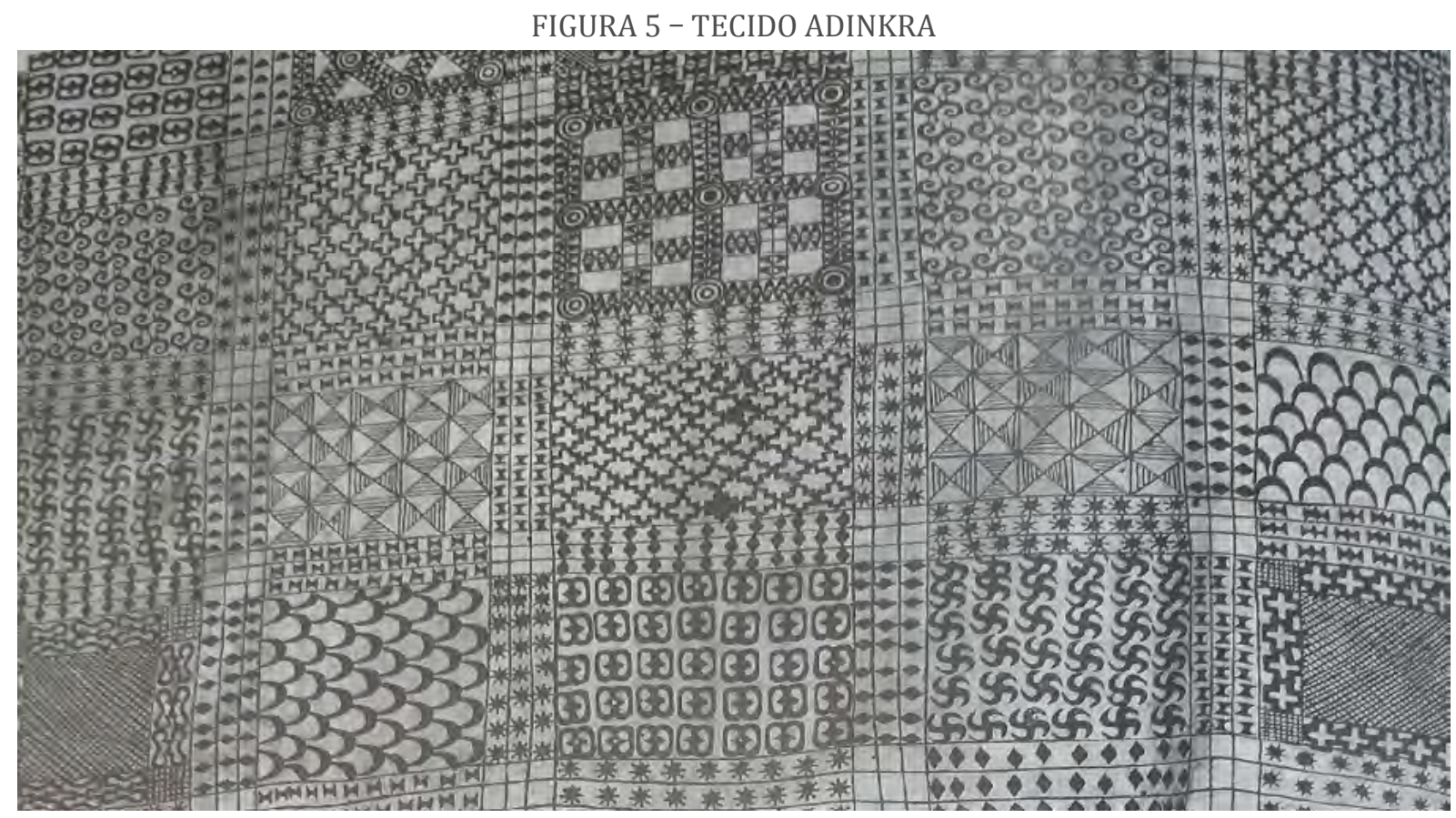

FONTE: PICTON, John; MACK, John. African textiles. 2. ed. London: British Museum, 1989.

Por fim, destaca-se que o Wax, último tecido que será abordado neste artigo, será por nós considerado africano, embora sua produção tenha sido iniciada por uma grande marca holandesa, atualmente dirigida por ingleses. Esse tecido veicula um repertório visual rico em estamparias étnicas das diversas culturas africanas e é amplamente comercializado e difundido pelas rotas comerciais internas na África e destas, posteriormente, para os mercados internacionais.

Ao longo da revolução industrial, a Holanda buscou expandir o mercado para escoar sua produção têxtil, de tal modo que vislumbrou, como oportunidade de negócios, produzir tecidos de alta qualidade para a Indonésia, território sobre o qual mantinha controle militar e econômico. Nesse contexto, destaca-se a história empreendedora de uma família holandesa que adquire uma máquina de estamparia para tecidos em algodão. Com familiares na Indonésia, ela começa a estampar panos com a técnica do batik, de origem javanesa, que utiliza cera na impressão. Dessa forma, buscava-se conquistar a população local da Indonésia na venda desses tecidos, chamados de Wax, nascidos da marca de design holandesa Vlisco, em 1846. 
O Wax adquire enorme repercussão quando recebe nomes dados pelas comerciantes africanas, ganhando assim um novo mercado de consumidores, que reconectam a estética projetada pelos designers internacionais da Vlisco à sua dimensão cultural e social africana.

É comum afirmarem que essas comerciantes foram as primeiras proprietárias de automóveis Mercedes-Benz no Togo (o que lhes valeu o apelido de Nanas Benz). Mas o que caracterizava acima de tudo era sua técnica de venda: para atrair sua clientela e tornar suas estampas desejáveis, começaram a nomeá-las com fórmulas evocadoras, que acompanhavam o desenho em todas as etapas da venda, do atacadista ao último caixeiro-viajante. 0 sucesso do "olho da minha rival", desenhado em 1949 por Bert Visser, pode ser compreendido tanto pelo aspecto hipnótico do desenho, de formas oblongas vermelhas sobre fundo amarelo, como pela escolha criteriosa de um nome que remete às difíceis relações das coesposas, numa época em que a poligamia ainda era o principal modelo matrimonial. (LEENHARDT; TITAN JR., 2018, p. 153)

A entrada do Wax holandês no mercado africano se efetiva quando a tradição local é revisitada e as identidades são recriadas por meio da nomeação dos tecidos que representam narrativas históricas reintegradas do global ao local.

\section{FIGURA 6 - ESTAMPA “OLHO DA MINHA RIVAL” - COLEÇÃO ANNE GROSFILLEY}

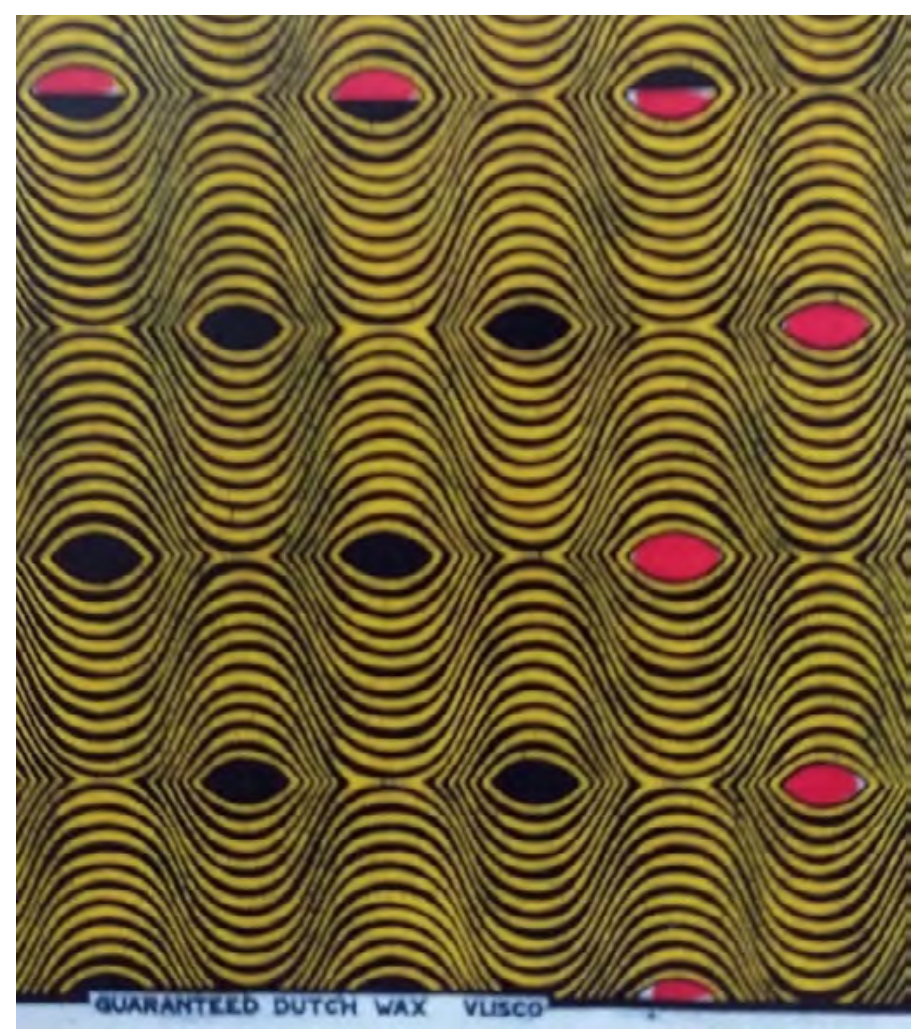

FONTE: LEENHARDT, Jacques; TITAN JR., Samuel (orgs.). Seydou Keïta. São Paulo: IMS, 2018. 
Portanto, todos os tecidos apresentados acima constituem uma forma de escrita que transmite símbolos culturais e narrativas históricas perpetuadas ao longo de gerações no continente africano e estão presentes no cotidiano de afrodescendentes no Brasil.

\section{Renovações de identidades}

Durante os trânsitos comerciais, tecidos têm sua identidade deslocada, tornando-se abertos e fragmentados. Em novos espaços, percorrendo caminhos e negociações, suas identidades são (re)construídas pelos discursos, práticas e posições que podem se cruzar ou serem antagônicos (HALL, 2006).

Segundo Rodrigues Jr. (2018, p. 82), a experiência de "cruzos" apontam as hibridações das identidades e suas ressignificações, operando como zonas culturais propositivas na formação de diálogos culturais. São esses espaços simbólicos, de atravessamentos múltiplos, que vão ampliar limites de discursos vigentes e as oportunidades a partir dos encontros provocados, reconstruindo "os elos de pertencimento alterados no trânsito e na impossibilidade de retorno" (RODRIGUES JR., 2018, p. 82).

\footnotetext{
Mas, hoje em dia, por conta da modernidade, muito se pegou, foi a questão das estampas, para efeito de industrialização. Aí entrou a Holanda, que teve a brilhante ideia de montar, construir uma empresa gigantesca sobre a questão dos tecidos, e aí então esses tecidos são fabricados lá na Holanda, mas não são usados pelos holandeses, não são vestidos pelos holandeses, e sim pelos africanos. (INFORMAÇÃO VERBAL) ${ }^{7}$
}

Nesse trecho da entrevista com o "administrador", podemos perceber os atravessamentos desses espaços propositivos, nos quais a estamparia de identidade africana é um recurso usado pela fábrica holandesa Vlisco para ampliar seu mercado consumidor de tecidos manufaturados. Sendo assim, uma equipe de designers do mundo todo, sediada na Holanda, desenha estamparias que veiculam símbolos, filosofias e tradições ancestrais africanos, produzindo tecidos que serão usados por africanos e seus descendentes em diáspora, graças aos elos de pertencimento entre esses indivíduos e sua identidade cultural estampada nesse bem de consumo. A partir da criação de estamparias que reúnem o repertório simbólico cultural de diferentes nações africanas, unida à estética e/ou ao simbólico europeu, a empresa holandesa faz uma história de sucesso de vendas, uma vez que esses produtos são exportados como “tecido africano" por comerciantes africanos para o mercado nacional e internacional.

O esquema teórico-analítico abaixo (figura 7) busca demonstrar as identidades dos tecidos analisados, suas renovações ao longo dos trânsitos comerciais e as zonas propositivas de "cruzos" e os hibridismos resultantes delas.

Nas entrevistas, foram verbalizadas as relações de identidade do tecido e as experiências sociais das quais ele participa, mostrando-se como um item que expressa códigos sociais locais.

Entrevista realizada com Entrevistado A, em São Paulo, no dia 12 de abril de 2019. 
O que eu estava explicando para ela [refere-se à pesquisadora] é essa questão de se vestir conforme as cerimônias, conforme as festas, conforme o que está acontecendo na aldeia, sei lá. [...] Uma coisa que mexe muito, mexe bastante com o imaginário da população da cidade. Uma madrinha de um casamento, você bateu o olho, você sabe que esta é madrinha, em um casamento, porque ela vai ter todo um tipo de adereços, de estampas de tecido que a identificam como a madrinha, entendeu? (INFORMAÇÃO VERBAL) ${ }^{8}$
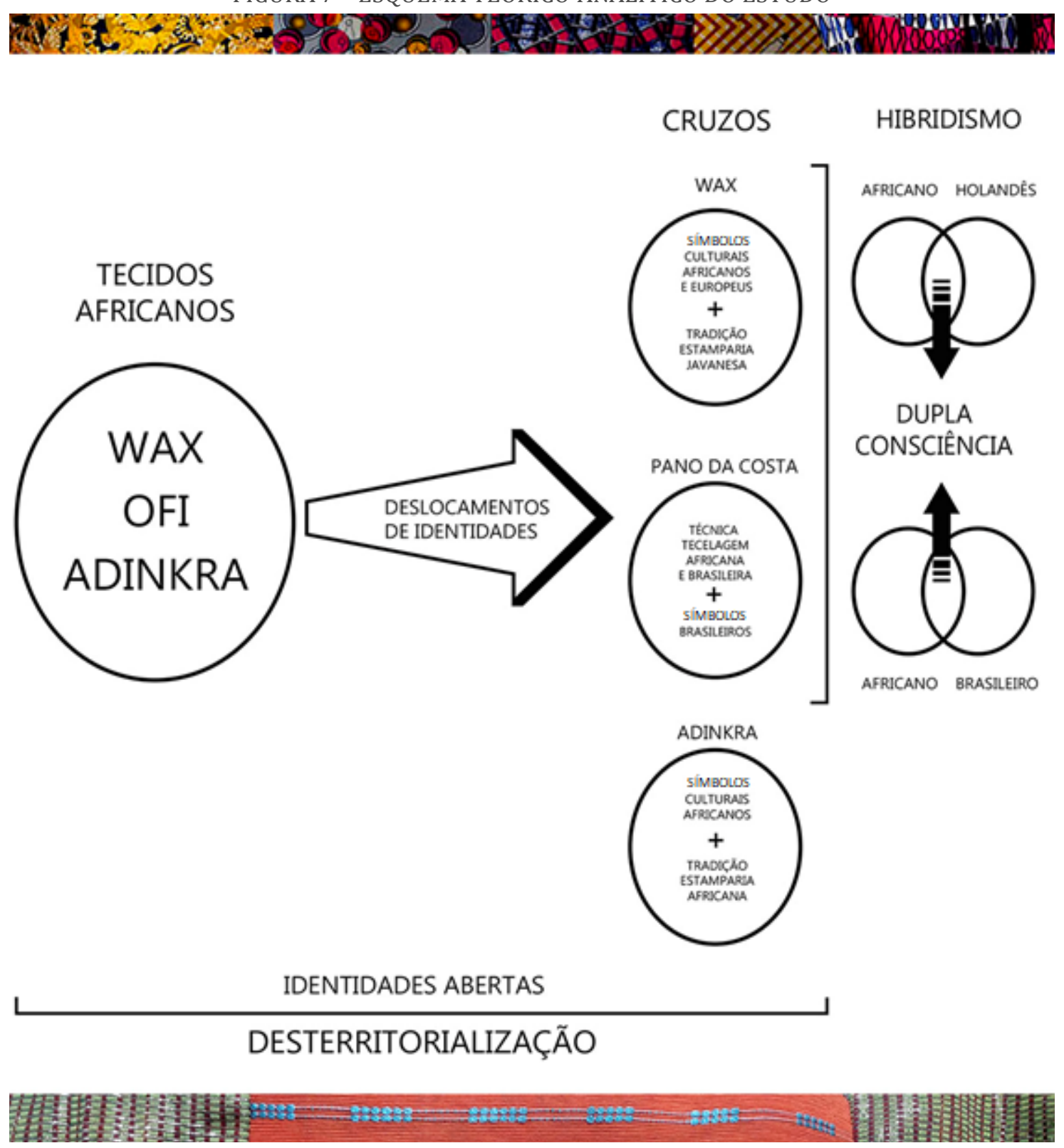

FONTE: Elaborado pelos autores.

\footnotetext{
8 Entrevista realizada com Entrevistado A, em São Paulo, no dia 12 de abril de 2019.
} 
O entrevistado "comerciante" destaca o Ofi/Pano da Costa na representação estética da cultura Yorúbà e os sentidos que ele ganha ao participar de eventos sociais importantes.

\begin{abstract}
Ofi é para casamento. Quando minha mãe morreu, todo mundo colocou Ofi porque minha mãe é uma grande pessoa lá na Nigéria. Meu pai é uma grande pessoa, eles usam. Roupa tradicional. [...] Não tem nenhum símbolo na roupa, não tem alguma coisa espiritual na roupa, o símbolo que é a beleza (ewa). [...] Porque a gente lá na Nigéria, a gente faz essas roupas e deixa que a beleza saia, entendeu? A gente não usa para orixá, cristão, muçulmano. [...] Em casamento, todo mundo usa. (INFORMAÇÃO VERBAL) ${ }^{9}$
\end{abstract}

O tecido Ofi assume grande importância na identidade cultural brasileira por assumir uma identidade própria no Novo Mundo, no Brasil. Originalmente, em território nigeriano, seu simbolismo estava vinculado aos valores socioculturais, às representações estéticas e aos eventos da cultura Yorùbá. A tradição de produção têxtil dessa peça está intimamente relacionada às práticas cotidianas, desde o seu fazer, que se inicia na infância, até o seu vestir. Na entrevista, o "comerciante" conta que se fôssemos até a Nigéria, poderíamos ver as crianças "brincando" com teares pela rua. Essa atividade também é uma prática pedagógica de ensino étnico-centrado, passada de geração para geração, durante a educação formal. 0 próprio "comerciante" esclarece: "Eu aprendi [...]. Eu brinquei com isso, não é para aprender que eu quero usar, é brincar [...]. A gente faz isso na escola, só brinca, para fazer alguma coisa" (INFORMAÇÃO VERBAL). ${ }^{10}$

$O$ entrevistado $C$ ainda chama a atenção para a importância dos têxteis africanos desde a formação básica, uma vez que existem, no continente africano, segundo ele, uma série de instituições e escolas que ensinam a prática da confecção e o manuseio de tecidos.

Essa característica de atribuição de valores socioculturais ao têxtil não se restringe ao tecido Ofi. Na entrevista, o "administrador" fala das estamparias veiculadas pelo tecido Wax e a atribuição mútua de sentidos ao participarem de construções sociais e simbólicas no cotidiano. Ele nos conta prazerosamente como os tecidos fazem parte e ganham valor a cada evento social em que se apresentam: "Para ele [tecido] ter valor agregado, você precisa fazê-lo participar das cerimônias tradicionais: casamento, batismo de criança, funeral, entendeu?" (INFORMAÇÃO VERBAL). ${ }^{11}$

$O$ entrevistado $A$ ainda ressalta as várias leituras possíveis por meio dos tecidos, das estamparias e das suas formas de uso em trajes sociais ao abordar o Adinkra e suas mensagens relacionadas aos funerais e à transmissão de valores ancestrais de geração para geração. Ele reforça a vasta possibilidade de interpretações sociais, correlacionando a estética e

\footnotetext{
9 Entrevista realizada com Entrevistado C, no Rio de Janeiro, no dia 23 de dezembro de 2018.

${ }^{10}$ Entrevista realizada com Entrevistado C, no Rio de Janeiro, no dia 23 de dezembro de 2018.

${ }^{11}$ Entrevista realizada com Entrevistado A, em São Paulo, no dia 12 de abril de 2019.
} 
seu simbolismo social a uma forma de escrita, com seus códigos próprios, afirmando "funeral é outra literatura gigante [...]" (INFORMAÇÃO VERBAL). ${ }^{12}$

Observamos até aqui indivíduos e tecidos que contam da vida cotidiana e constroem identidades a partir de suas histórias, de forma que a interação social e A criação de sentidos se dão e se completam mutuamente. Podemos interpretar essa "literatura gigante" como uma maneira de aprofundar inteligibilidades sobre o que acontece na vida social, pela análise desses tecidos e estamparias que ganham a dimensão de agentes no cotidiano africano e de seus descendentes em diáspora. Percebemos que ao se referir ao tecido Wax, o "administrador" personifica-o e apresenta seu protagonismo nas práticas cotidianas.

Mas o Wax, para poder penetrar, adentrar, vamos dizer assim, no dia a dia afri-
cano, para isso acontecer, ele de uma forma inconsciente serviu-se das mulheres
que hoje se chamam Nana Benz. Elas simplesmente olhavam para o tecido, tenta-
vam visualizar ali alguma representação simbólica de algumas situações de vidas
das mulheres africanas ou da sociedade africana e o denominavam, davam um
nome específico ao tecido. (INFORMAÇÃO VERBAL)

Ao longo dos seus deslocamentos, têxteis africanos e seus comerciantes irão incorporar novos significados e (re)valorizar tecidos e identidades. Nesse sentido, o tecido Ofi/Pano da Costa irá negociar novas identidades ao ampliar sua dimensão de identidade estética e cultural, assumindo a identidade religiosa no Brasil. Como forma de (re)existência, esse tecido se perpetuará nas práticas, nos ritos e na tradição de produção têxtil em novo espaço social: nos terreiros de religiões de matrizes africanas brasileiros. Nosso entrevistado "comerciante" chama a atenção para isto, apontando tal dinâmica como um "problema", na sua percepção, uma vez que o tecido Ofi/Pano da Costa ganha novo significado e se distancia da identidade inicial de origem africana.

Esse é o problema que aconteceu aqui no Brasil, essa roupa serve para religião, cristão, muçulmano, aqui, religião umbanda, aqui [...]. Não gosto [referindo-se aos usos da roupa no Brasil]. Lá na Nigéria, o que seria de religião, não é isso. Lá [na Nigéria] é cultural! Roupas são coisas culturais, não tem nada a ver, não tem cor de Oxum na roupa, entendeu? (INFORMAÇÃO VERBAL) ${ }^{14}$

Na fala acima, o entrevistado C evidencia a dimensão e a expressão religiosa assumida no Brasil, que se apresentaram como "uma solução" para afrodescendentes por possibilitarem que fosse perpetuada a tradição de tecelagem entre os membros praticantes das religiões de matrizes africanas. No espaço sagrado, o Ofi/Pano da Costa recebe novos simbolismos relacionados às divindades africanas cultuadas no Brasil, podendo ser tecido por homens e mulheres, sendo elas as maiores mantenedoras dessa tradição.

\footnotetext{
12 Entrevista realizada com Entrevistado A, em São Paulo, no dia 12 de abril de 2019.

${ }^{13}$ Entrevista realizada com Entrevistado A, em São Paulo, no dia 12 de abril de 2019.

${ }^{14}$ Entrevista realizada com Entrevistado C, no Rio de Janeiro, no dia 23 de dezembro de 2019.
} 
Na dimensão de patrimônio, nos dias de hoje, o tecido Ofi/Pano da Costa busca retornar à sua identidade inicial africana, a cultural, oscilando ora entre a dimensão religiosa, ora entre a dimensão cultural.

Abordando novas tramas e estamparias, encontramos, em Gana, o tecido Adinkra, conhecido pelo uso por parte da realeza ganense. Tal trama significa "adeus" e, portanto, está inicialmente relacionada aos rituais fúnebres e popularizados em festivais de homenagens, como foi apontado pelo "administrador".

Assim como os demais tecidos, o Adinkra ganha valor sendo exibido de eventos sociais, porém, por transportar um rico repertório de símbolos, com filosofias ancestrais em sua estamparia, por meio do pan-africanismo adquire grande importância em territórios que receberam a diáspora africana. Segundo Nascimento e Gá, a estamparia Adinkra exercerá o papel de "recuperar a dignidade humana desses povos" porque, pelo "conhecimento e desenvolvimento, permeiam a história da África, em sistemas de escrita, avanços tecnológicos, estados políticos organizados, tradições epistemológicas" (NASCIMENTO; GÁ, 2009, p. 22).

Na entrevista com a "estilista" foi ressaltada a presença de símbolos Adinkras em espaços urbanos cariocas, ou seja: tal escrita teve como suporte não só os tecidos, mas ela contribuiu para a identidade afro-brasileira, marcando a passagem de povos africanos que desenvolveram papéis específicos na construção das cidades.

\begin{abstract}
Você sempre vai ver este Adinkra em todos os portões, portas, do Rio de Janeiro, é esse [...] mais popularmente é este Adinkra, o Sankofa, que tem esta variação, é a variação do pássaro, que é a questão de olhar para trás. E aí eu fui pesquisar porque em tantos portões do Rio têm símbolos africanos. Os colonizadores [...] existia uma necessidade de determinada função, então foi se pesquisar quem seriam as melhores pessoas para exercer essa função, e aí, as pessoas da Costa do Ouro, onde se localiza Gana e outros países que são muito ricos em vários metais e já tem conhecimentos ancestrais sobre fundição e tal, e aí foram estes os africanos sequestrados e trazidos para cá, então ter os Adinkras registrados nas portas na hora de eles fazerem este trabalho é uma forma de dizer para toda a comunidade que alguma hora eles voltariam para a África, e parte voltou, são os Agudás. (INFORMAÇÃO VERBAL) ${ }^{15}$
\end{abstract}

A entrevistada E destaca ainda algumas das filosofias presentes nas estamparias Adrinkra. No seu relato, ela apresentou suas estampas feitas a partir desses símbolos e compartilhou seus significados:

O Sankofa é o pássaro olhando para trás, ele fala de você entender seu presente, olhar para o passado, entender seu presente para fazer um futuro diferente, ele fala muito disso, da sabedoria ao olhar para o passado [...] este é o dos crocodilos

${ }^{15}$ Entrevista realizada com Entrevistada E, no Rio de Janeiro, no dia 04 de agosto de 2018. 
siameses, um dos meus favoritos também, que fala sobre unidade, enquanto tivermos o mesmo destino. Enquanto um crocodilo come, o outro come também. Porque têm o estômago unido. (INFORMAÇÃO VERBAL) ${ }^{16}$

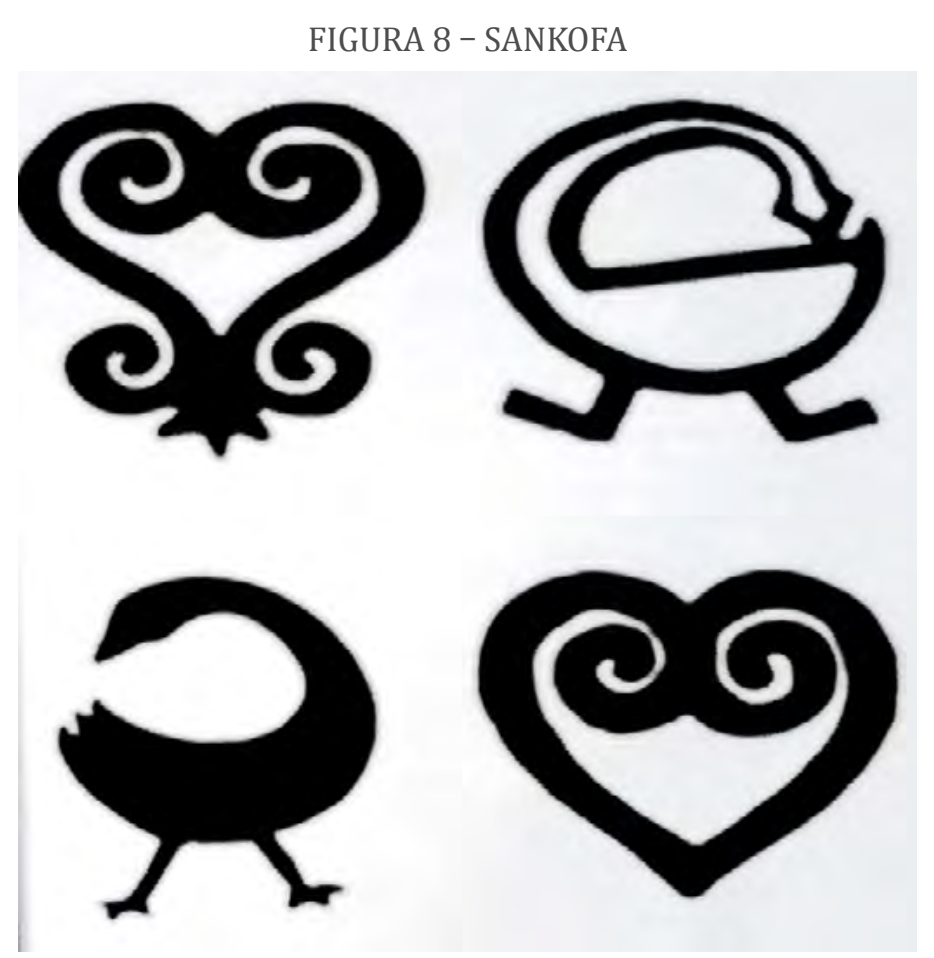

FONTE: NASCIMENTO, Elisa Larkin; GÁ, Luiz Carlos (orgs). Adinkra: sabedoria em símbolos africanos. Rio de Janeiro: Ed. Pallas, 2009.

A Entrevistada E ressaltou ainda sua missão como estilista e angolana no Brasil, de todos os dias relembrar a riqueza do continente e de suas sabedorias. Ao apresentar a filosofia Sankofa, a estilista busca perpetuar a transmissão de conhecimentos das culturas africanas pelo uso de simbologias na estamparia de seus produtos, acompanhados de uma tag que explica o conteúdo do ideograma para o consumidor. A estilista objetiva, por meio da moda, levar os conhecimentos ancestrais africanos para a maior quantidade possível de brasileiros. Por sua vez, afrodescendentes paulatinamente incorporam a simbologia Adinkra em seu cotidiano como elo de pertencimento e orgulho étnico, seja no corpo, em tatuagens, relembrando as escarificações que marcaram a descendência étnico-cultural de escravizados ao chegarem ao Brasil, seja na indústria criativa, em logotipos de empresas ou mesmo em roupas ou papelarias estilizadas.

Como última parada da nossa viagem pelas tramas e estampas, analisaremos a comercialização e a distribuição do tecido Wax, proveniente da Holanda e de suas fábricas implementadas em diferentes partes do mundo, para alimentar grande parte da África Ocidental e dos países que receberam fluxos de africanos escravizados.

${ }^{16}$ Entrevista realizada com Entrevistada E, no Rio de Janeiro, no dia $\emptyset 4$ de agosto de 2018. 
Na entrevista realizada com o "comerciante", foi afirmada a identidade do tecido Wax como africana e também nigeriana; ele ressalta a importância da matéria-prima, o algodão nigeriano, para a produção holandesa que, no seu ponto de vista, é apenas tecnológica: "A Holanda não tem árvore de algodão [...] pergunta para eles: onde é que se planta? Se [o algodão] está no país deles? A Holanda entra com a tecnologia, a experiência, eletrônica, só! Entendeu? De onde a roupa vem é da Nigéria" (INFORMAÇÃO VERBAL). ${ }^{17}$

Esse tecido de valor industrial começa a ganhar valor cultural e, por consequência, monetário em territórios africanos, à medida que os repertórios simbólicos veiculados nas estampas ganham sentido nas palavras das vendedoras locais, as Nanas Benz. Ao longo das entrevistas, o "administrador" ressalta essa revalorização do tecido e da instalação das fábricas Vlisco em países africanos:

O valor dele [tecido Wax] é porque ele é de extrema qualidade mesmo, só isso!
Eles não têm lá valor cultural. Então é a partir do uso social que o tecido vai
ganhando valor [...]. Essas mulheres [referindo-se às Nanas Benz] são criativas
demais, tem cada coisa...eu lembro de um tecido que era chamado de si ti em sors,
je sors, que significa "se você sair da casa, tipo para fazer a vida lá, eu também vou
sair". Ou seja, se o marido fala que não, eu não estou nem aí, hoje vou sair para
fazer [...] eu também saio. Esse tecido era feito com uma gaiola, dentro da gaiola
tinha um passarinho com a janelinha aberta ${ }^{18}$. (INFORMAÇÃO VERBAL) ${ }^{19}$

Hoje a equipe de designers de estampas Vlisco está alocada na Holanda, e foram instaladas fábricas de impressão em países africanos, tais como Costa do Marfim e Gana, também há fábricas na Inglaterra e cópias feitas na China. Podemos mapear a origem da impressão desses tecidos pelas etiquetas e garantias, que apresentam assinaturas na borda de cada tecido Wax, porém, com as disputas pela sua lucrativa comercialização, as etiquetas e garantias são copiadas e reproduzidas por fabricações chinesas, por exemplo, que buscam ganhar o prestígio e o valor cultural da trama.

Os entrevistados apontaram também o movimento crescente de novas fábricas de tecidos estampados criadas e geridas por africanos em seus respectivos países de origem, sem interferência estrangeira. Sobre esse fato, o "comerciante" apontou que a Nigéria está "acordando" em termos tecnológicos, e o "administrador" complementou que as indústrias de tecidos legítimos africanos se reapropriaram novamente do seu repertório simbólico, tendo como base as estampas do tecido Wax holandês, mais popularizadas ao longo do comércio realizado pelos vendedores do país.

Essa disputa pelas apropriações e reapropriações é intensificada com a entrada da China no comércio de tecidos e estamparias "africanas". Essa potência, tendo em vista o negócio lucrativo de tecidos estampados para africanos, começa a copiar os Wax e passa a usar as mesmas assinaturas na barra do pano, de forma a confundir totalmente o consumidor.

\footnotetext{
17 Entrevista realizada com Entrevistado C, no Rio de Janeiro, no dia 23 de dezembro de 2019.

18 Descrição da estampa.

19 Entrevista realizada com Entrevistado A, em São Paulo, no dia 12 de abril de 2019.
} 
E o "administrador" explica: "É um mercado onde você tem a intervenção de vários países hoje em dia, a China [...] ela sabe que o pessoal compra quando vê "super wax", então ela faz e coloca "super wax" [na etiqueta]" (INFORMAÇÃO VERBAL). ${ }^{20}$

A esse jogo de apropriações culturais adicionamos a Holanda que, ao se ver ameaçada pelas cópias chinesas, passa a associar os tecidos de identidade africana a um tradicional design holandês, como exibiu Bruggeman (2017) a partir de uma entrevista do diretor da Vlisco, Roger Gerards: "Nós [Vlisco] somos muito falados, decorativos - e nós somos design holandês, totalmente feito em um ambiente holandês" (BRUGGEMAN, 2017, p. 205). Percebemos que as informações técnicas impressas nos tecidos foram alteradas para guaranted dutch wax vlisco, reforçando a intencional apropriação cultural desses tecidos pela Holanda, que passa a apresentá-los em mercados de venda ou nas exposições de design internacionais como produto de identidade holandesa.

No Brasil, esse tecido será a principal manufatura têxtil trazida por imigrantes africanos, na atualidade, para os grandes centros urbanos, como destacou o Centro de Estudos das Relações de Trabalho e Desigualdades (Ceert).

As ruas do centro da cidade de São Paulo estão cada vez mais coloridas. Os estampadíssimos tecidos africanos têm ganhado espaço no comércio popular, graças ao aumento de vendedores destes artigos, em sua maioria imigrantes do Senegal, Angola e Moçambique. (EIRAS, 2015, s. p.)

Ao longo da fala do entrevistado $\mathrm{C}$, ainda foi ressaltada a chegada desses tecidos no Brasil em containers, por navios; ou carga, por aviões, comprados diretamente por brasileiros ou trazidos por comerciantes africanos fornecedores das principais feiras de artigo populares, como a de São Joaquim, em Salvador. As peças de tecido serão usadas por brasileiros que reivindicam a identidade étnica e cultural africana, seja no cotidiano ou em práticas religiosas, ao usarem roupas e/ou turbantes feitos com tecidos Wax. Esse pano é o principal artigo que irá atender o mercado crescente da moda afro-brasileira, fomentado por empreendedores brasileiros que veem nessa moda uma oportunidade de atender o público de afrodescendentes no país.

\section{Considerações finais}

As perspectivas pós-coloniais emergem dos discursos dos países do terceiro mundo e das "minorias" que irão intervir na narrativa do discurso hegemônico, apresentando histórias diferenciadas, sejam elas raciais, nacionais, de comunidades ou de povos.

Lopes e Falcón (2010) ressaltam a importância dos anos 1970 para a população negra no Brasil, como um período no qual se buscou reforçar as heranças africanas no país, com o fortalecimento da autoestima e a reivindicação dessa identidade por meio de um movimento estético, político e social. Nesse contexto, a estética afrodescendente terá como instrumento de conexão os tecidos estampados que veiculam identidades africanas; que irão compor a performance de afrodescendentes brasileiros, acionando um papel de costura de

20 Entrevista realizada com Entrevistado A, em São Paulo, no dia 12 de abril de 2019. 
tramas e (re)conexões da origem étnica como forma de afirmação identitária e de valorização das heranças africanas no Brasil.

0 tecido Adinkra tem sua estamparia difundida entre um ciclo mais restrito de afrodescendentes, em especial acadêmicos, pesquisadores, especialistas e artistas, fazendo parte do repertório imagético afro-brasileiro nas criações de designers brasileiros que buscam criar coleções de moda que trazem a filosofia Adinkra em estampas com tags explicativas. 0 repertório é ampliado para outros movimentos artísticos, como o cinema e a literatura, e para a paisagem urbana, como nos foi apresentado na entrevista da "estilista". Esses símbolos contarão histórias e vão reverberar valores e cosmovisão africana entre descendentes e cidadãos diaspóricos.

O tecido Ofi/Pano da Costa se mantém vivo e com importância litúrgica nos espaços de difusão das religiões de matrizes africanas. Sua presença é fundamental para que as cerimônias aconteçam, assim como para o estabelecimento de hierarquias internas da religião por meio da vestimenta. Busca-se que o Ofi/Pano da Costa assuma cada vez mais o caráter cultural a fim de ampliar seu mercado de consumo e a tradição da produção do tecido para além da demanda segmentada dos praticantes de religiões de matrizes africanas no Brasil.

Ambos os tecidos estão mais restritos a ambientes de nicho, de convívio e contato dos afrodescendentes, porém, exercendo papéis de alicerces para a (re)construção e (re) existência identitária africana no Brasil.

Aos tecidos Adinkra e Ofi/Pano da Costa, fazemos o contraponto com o Wax, que assume caráter mais popular, no uso mais ampliado entre simpatizantes e amantes da cultura afro-brasileira. O Wax é o mais usado hoje no Brasil, representando o senso de comunidade e a valorização da descendência africana no país de forma política e/ou por afinidades simplesmente estéticas.

0 tecido Wax destaca-se entre os demais por causa da sua oferta mais abundante no comércio de "tecidos africanos", e ainda por abarcar as estampas Adinkra e do Ofi/ Pano da Costa, que originalmente são produzidas manualmente, e irão ganhar escalabilidade por meio da produção das fábricas têxteis ditas holandesas, quando seus símbolos ou tramas são digitalizadas na estamparia do tecido Wax, que se apropriará do repertório imagético das principais expressões culturais africanas e os transformará em manufaturados têxteis.

O tecido Wax irá se popularizar e permitir o acesso aos tecidos que originalmente são caros e demandam grande tempo de produção artesanal com o processo de impressão de estamparias digitais sobre base de tramas de algodão africano. Ele ainda vai movimentar uma ampla cadeia de comércio e consumo no Brasil, envolvendo, na sua distribuição, comerciantes africanos vindos do continente para realizar vendas locais, de maneira informal em comércio popular, nas ruas dos grandes centros urbanos, como Rio de Janeiro e São Paulo. Esses vendedores irão repassar os chamados "tecidos africanos" a consumidores finais e a empreendedores de moda afro-brasileira que produzem modelos brasileiros. Essa é uma ampla cadeia de mercado, que exibe um aumento do desenvolvimento e do empreendedorismo afro-brasileiro de $43 \%$ para $49 \%$ no segmento das micro e pequenas empresas, com destaque para a iniciativa empresarial nos setores de moda e estética afro-brasileira (BARRETTO, 2014). Na maior parte dessa da cadeia de produção, não se 
apresentou discussão crítica sobre a origem desse tecido e da criação da estamparia ser holandesa. 0 tecido no Brasil é usado por afrodescendentes como reafirmação identitária e ainda por ativistas do movimento negro que, ao se depararem com o fato de serem criados originalmente na Holanda, são tomados por sentimento de frustração.

No decorrer da pesquisa e das análises expostas ao longo deste estudo, percebemos o amplo processo de revalorizações e apropriações desses bens culturais e as disputas por hegemonias culturais cada vez mais evidenciadas pelo capitalismo. Sobre elas, destacamos a agência africana que se faz presente a partir das práticas cotidianas e das formas de reapropriações culturais que africanos protagonizam, reforçando a identidade cultural dos tecidos e das estamparias como africanas, independentemente de quem ou do local onde estão sendo produzidas e comercializadas.

Nas diversas hibridações desses tecidos, compreendemos que seus sentidos não se esgotaram na morte, frente ao apagamento e à apropriação cultural por uma cultura hegemônica ou um sistema econômico. Percebemos que no esgotamento do ser tomado como essencial, abre-se a possibilidade para além do problema da morte simbólica, dando vida à reinvenção da existência, das identidades e suas formas de representação em novos territórios e no próprio território de origem.

Deste ponto de vista, o mundo não é mais percebido como uma ameaça; pelo contrário, ele é imaginado como uma vasta rede de afinidades. Em contraste com as mitologias unanimistas, o ponto essencial é que todos podem imaginar e escolher o que o(a) torna africano. (MBEMBE, 2001, p. 186)

Mbembe (2001) anuncia, em perspectiva filosófica, que devemos nos ater às experiências africanas de mundo, que escapam à determinação, e nos recomenda a ideia de que a história é feita processualmente em afirmações de africanidade, que estão em constante negociação, adquirindo novas posições nos espaços e entre culturas, rompendo os signos de identidade e diferença e inscrevendo sua estética atrelada aos valores socioculturais. Rodrigues Jr. (2018) aponta os caminhos possíveis ao pós-colonialismo, que podem revelar uma pluralidade de experiências existentes no mundo. A decolonialidade nos estimula à reflexão da "vida", do que se forma após o evento da colonização, tendo nos tecidos e nas suas narrativas a partir de suas estamparias uma ferramenta importante seja para a educação, seja para a compreensão da diversidade identitária e cultural por meio da produção da moda e do têxtil com identidade afro-brasileira.

Propomos que possamos refletir sobre os processos identitários no Brasil, podendo problematizá-los e ampliá-los a partir de ferramentas e narrativas que possibilitem a formação de um pensamento crítico ampliado, que possam alargar limites de discursos vigentes, trazendo novas formas de pensamento e de construção do sentido de ser e de pensar nossa existência. Histórias podem ser contadas e ressignificadas a partir de objetos que participam do nosso cotidiano e que, enquanto patrimônio, perpetuaram memórias e expressões identitárias híbridas.

Ressaltamos a importância da moda como um relevante segmento para continuar em foco nos debates relativos às políticas públicas, em especial a moda com identidade 
afro-brasileira, por se apresentar como um instrumento de preservação da memória nacional e de grande potencial econômico, atendendo a uma ampla cadeia de produção que une comércio, indústria, cultura, educação e entretenimento.

\section{Referências}

ADLER, Peter; BARNARD, Nicholas. African majesty: the textile art of the Ashanti and Ewe. London: Thames and Hudson, 1992.

BANDEIRA, Pedro Correa; LAGO, Julio. Debret e o Brasil: obra completa. 4. ed. Rio de Janeiro: Editora Capivara, 2013.

BARDIN, Laurence. Análise de conteúdo. 6. ed. São Paulo: Edições 70, 2011.

BARRETTO, Luiz. Uma opção democrática para ascensão profissional. 2014. Disponível em: http://www.institutoiab.org.br/bancodeconhecimento/desenvolvimento-e-empreendedorismoafro-brasileiro/. Acesso em: 27 nov. 2017.

BRUGGEMAN, Danielle. Vlisco: made in Holland, adorned in West Africa, (re)appropriated as Dutch design. Fashion, Style \& Popular Culture, v. 4, n. 2, 2017, p. 197-214. Disponível em: https://doi.org/10.1386/fspc.4.2.197_1. Acesso em: 15 dez. 2019.

CARISE, Iracy. A arte negra na cultura brasileira. Rio de Janeiro: Editora Artenova, 1974.

DU BOIS, William Edward Burghardt. The souls of black folk. New York: Dover Publications, 1994.

EICHER, Joanne Bubolz. Nigerian handcrafts textile. Ilê-Ifé: University of Ifé Press, 1976.

EIRAS, Natália. Moda afro: no centro de SP ou na internet, a negritude ganha força fashion. Ceert. 2015. Disponível em: https://www.ceert.org.br/noticias/historia-culturaarte/8801/moda-afro-no-centro-de-sp-ou-na-internet-a-negritude-ganha-forca-fashion> Acesso em: 20 nov. 2015.

FERREIRA, Larissa. Corpos moventes em diáspora: dança, identidade e reexistências. Revista da Associação Brasileira de Pesquisadores/as Negros/as (ABPN), v. 11, n. 27, 2019, p. 50-63.

GILROY, Paul. 0 Atlântico negro: modernidade e dupla consciência. São Paulo: Editora 34, 1993. 
GOFFMAN, Erving. A representação do eu na vida cotidiana. 13. ed. Petrópolis: Editora Vozes, 2014.

GOMES, Nilma Lino. O Movimento negro educador: saberes construídos nas lutas por emancipação. Petrópolis: Editora Vozes, 2017.

HALL, Stuart. Identidade cultural na pós-modernidade. 11. ed. Rio de Janeiro: Editora DP\&A, 2006.

LEENHARDT, Jacques; TITAN JR., Samuel (orgs.). Seydou Keïta. São Paulo: IMS, 2018.

LODY, Raul. Moda e história: as indumentárias das mulheres de fé. São Paulo: Editora Senac, 2015.

LOPES, Goya; FALCÓN, Gustavo. Imagens da diáspora. Salvador: Solisluna Editora, 2010.

MAURÍCIO, Jorge da Silva. O Pano da Costa. In: BAHIA - Governo do Estado (org.). Pano da Costa: Cadernos do IPAC, 1. Salvador: IPAC, 2009, p. 12-16.

MBEMBE, Achille. As formas africanas de autoinscrição. Estudos Afro-Asiáticos, v. 23, n. 1, 2001, p. 171-209. Disponível em: http://dx.doi.org/10.1590/S0101-546X2001000100007. Acesso em: 10 dez. 2019.

NASCIMENTO, Elisa Larkin; GÁ, Luiz Carlos (orgs). Adinkra: sabedoria em símbolos africanos. Rio de Janeiro: Editora Pallas, 2009.

PICTON, John; MACK, John. African textiles. 2. ed. London: British Museum, 1989.

RODRIGUES JR., Luiz Rufino. Pedagogia das encruzilhadas. Revista Periferia, v. 10, n. 1, 2018, p. 71-88. Disponível em: https://doi.org/10.12957/periferia.2018.31504. Acesso em: 10 nov. 2019.

RUGENDAS, Johann Moritz. Viagem pitoresca através do Brasil. Belo Horizonte: Editora Itatiaia, 1998.

SANSONE, Livio. Os objetos da identidade negra: consumo, mercantilização, globalização e a criação de culturas negras no Brasil. Revista Mana, v. 6, n. 1, 2000, p. 87-119. Disponível em: http://dx.doi.org/10.1590/S0104-93132000000100004. Acesso em: 10 dez. 2019.

SILVA, Rosyane Maria da. Iquiya: sobre significados e simbologias de uso de turbantes por mulheres negras. Revista da Associação Brasileira de Pesquisadores/as Negros/as (ABPN), v. 10, Ed. Esp., 2018, p. 124-148. 
VIDAL, Julia. 0 africano que existe em nós, brasileiros: design e moda afro-brasileiros. Rio de Janeiro: Babilonia Cultura Editorial; Fundação Biblioteca Nacional, 2014.

WILLIAM, Rodney. Apropriação cultural. São Paulo: Ed. Pólen, 2019.

Agradecimentos

Os autores agradecem profundamente à Coordenação de Aperfeiçoamento de Pessoal de Nível Superior (CAPES) e ao Centro Federal de Educação Tecnológica Celso Suckow da Fonseca (CEFET-RJ) pelo apoio recebido de ambas as instituições ao longo da condução da pesquisa que subsidiou este artigo. 